\title{
Religion as a social adhesive: study of the patterns of religious diversity of rural communities in the village of Sembungan- Boyolali
}

\author{
Sarbini Sarbini ${ }^{1,}{ }^{*}$, Putut Suharso ${ }^{2,3}$, Dicky Sumarsono ${ }^{3}$ \\ ${ }^{1}$ Faculty of Ushuludin and Da'wah - IAIN Surakarta, Pandawa Street, Pucangan, Kartasura, Sukoharjo \\ 57168, Indonesia \\ ${ }^{2}$ Department of Library and Information Science, Diponegoro University, Prof. H. Soedarto SH \\ Street, Semarang 50275 Indonesia \\ ${ }^{3}$ Postgraduate Program in Cultural Studies, Sebelas Maret University, Ir. Sutarmi 36A Street, \\ Surakarta 57126, Indonesia
}

\begin{abstract}
For rural communities, religion is understood as the core of the value system to control the actions of the community in order to remain sustainable in accordance with the values of the religious teachings. Religious behavior is a sacred symbol that is based on religious teachings. This study uses a sociology of religion approach that attempts to describe the empirical reality of religious communities related to doctrine, beliefs, social behavior and functional teachings that give birth to religious phenomena. Research methods by collecting data through observation, interviews, and smoothing documentation that is narrated in descriptivequalitative form with descriptive-interpretive analysis. The results of the study of rural communities have a tendency to make new meanings in sustainable life towards a system of values and religious norms that are confident and internalized in a homogeneous community environment, and express values of appreciation in the form of efforts to maintain togetherness through functional religious messages. When the new meaning of individuals in society results in an interest conflict that is influenced by the individual's social status, then the power of transcendent values is needed. The discovery of this new transcendent meaning is then called the awareness of social collectivity in society.
\end{abstract}

\section{Introduction}

The value changes in the industrial society will affect the pattern of religious understanding for rural communities. In the LCA (Life Cycle Assessment) perspective, the dominant values in the industrial society are dehumanization. In the dehumanization process, religion has a role to overcome, adjust and develop the excesses of change. In the religious life, it requires balance \& sustainability (SDGs) to find the ultimate meaning of life by avoiding

\footnotetext{
* Corresponding author: sarbinidamai@gmail.com
} 
the negative thoughts and prioritizing the positives [1]. Religion is a social phenomenon that can affect the social situation and conditions of the community. As a social phenomenon, religion has a close relationship and influence with the system and structure of society. Radcliffe-Brown [2] in his book "Structure and Function in Primitive Society" said that in society there is always a strong relationship between religion and the arrangement of society. Religion functions as a supervisory institution for the social actions of the community as well as a driving force and controlling tool for its adherents in a community structure.

The manifestation of religion can be seen from a series of religious ceremonies carried out by religious leaders and followed by its adherents. The religious ceremony is the face of the existence of religion with all its functions. Even extremely it is said that if religion does not carry out religious ceremonies on a continuous basis, then the religion dies. Therefore, religion has a tradition that is always carried out to maintain balance and harmony within the community.

Schneier [3] states that religion has a doctrinal dimension that has the power to change character, if religion is held sincerely. On the other hand, religion is a need for expression of sancity and for modern society religion is associated with mental and spiritual life. Thus the socio-religious identity in the community is in the form of social interactions that give birth to religious dynamics by constructing religious identity for the sake of a more harmonious life in the form of religious integration with modern culture.

Koentjaraningrat [4] describes the prominent features of rural communities is the strength of mutual cooperation activities in terms of; (1) events of death, illness or accident, where families who are suffering get help in the form of energy and objects from their neighbors; (2) in the case of work around the household, such as repairing the roof of the house, replacing the walls of the house, digging wells, the homeowner can ask for help from nearby neighbors, by giving a meal; (3) matters of wedding parties, to prepare and organize parties; (4) community service: work for the public interest in rural communities, such as repairing roads, bridges, irrigation channels, public buildings. Social relations of any kind in the countryside are never merely of a utilitarian and instrumental nature (never solely based on considerations of usability and are considered mere tools). Every social relationship such as mutual cooperation is always surrounded by symbolic constructs that explain, justify and regulate it.

From the structure of the rural community above, departing from Whitehead [5] thinking religion in society has 4 aspects. First, religion as a way of life can be felt deeply by a person. Second, religion as an individual life that relates to society as a whole of morals and feelings. Third, religion is a value that is relevant to real life. Fourth, religion as a human response to the development of the world that continues to experience change. This study assumes that the people of Sembungan Kec. Nogosari has a religious pattern; (1) Traditional, that is the way of religion based on tradition, following what is done by ancestors, ancestors or previous people; (2) Formal, that is the way of religion based on the formalities prevailing in the community, following the various patterns of people who have a high position and have influence. People who are not strong in religion, easily influenced by the environment even willing to exchange their religion for their own sake; (3) Rational, that is religion based on the use of ratios. They try to understand and live the teachings of their religion with their knowledge, cognition and practice; (4) Emotional, which is a way of religion based on feelings with the guidance of revelation.

Modernity has a tendency to avoid religions that are considered to be stable and unable to respond to spiritual quests. Religion is only conventional, it only adds spiritual schools, religious sects or cults that offer exclusive contemplative rites that give more value to their spiritual thirst. This is a form of spirituality without formal religion, namely diversity which only takes its spiritual dimension [6]. From the academic problem above, this study is to 
answer questions; (1) What is the function of religion for the countryside, and (2) What kind of attitudes are developed by rural religious communities?

\section{Research method}

The research method used in this research is descriptive analytical method, with a qualitative approach [7]. Descriptive method is used to describe the status of a human group, an object, a conditions of system of thought, an event at an ongoing time. The qualitative approach used in this study is intended so that researchers can understand the patterns of religious practices in rural communities.

Thus this descriptive research method is considered suitable to describe the religious patterns that occur in society life [8]. The data analysis method used is qualitative analysis. Qualitative data analysis is defined as an analysis effort based on words compiled into the required text form. In this research, data from interviews and observations are written in a detailed field note, the data from the field notes will be analyzed qualitatively.

\section{Result and discussion}

\subsection{Social structure}

In the 1950s, Koentjaraningrat [9] divided the coating of rural communities into an elite class of landowners, agricultural laborers and the poor. However, it is currently undergoing a change. At present, the social structure of the village community is based on status and role, not assets owned. According to Linton, a person carries out a role when he carries out the rights and obligations which constitute his status, both ascribed status and the achieved status. Whereas in the context of the role of the main village structure namely the structure of the communal community and the structure of the village authority. Communal is a small and homogeneous communities which is marked by prominent social relations and bound to traditional culture. The pattern of social relations is built on ties of neighborhood, kinship and religion [10]. In contrast to housing communities whose kinship patterns tend to be more individualistic. While the authority structure is based on the pattern of social relations in the village government, with the pattern of organizational relations, such as relations between RT, RW and village government.

In the structure of rural communal society involves two main social groups namely community leaders and ordinary people. Community leaders consist of RW administrators, RT Administrators, Takmir Mosque Management, Lecturers, and other officials, or wealthy entrepreneurs. Ordinary community groups consist of workers, peasants, and others who have ordinary economy. This communal relationship is a cooperative relationship in the framework of vertical solidarity. This relationship is personal and legitimized by societal values in the form of collective action in the form of community service work, social fund contributions and pirukun (RW-nan activities, RT-nan, helping people, death).

The social structure of the rural community is homogeneous, does not have diversity, ranging from social classes, ways of social interaction and even social stratification [11]. Socially, rural residents are formed by common interests, namely the realization of harmony communities.

\subsection{Religious structure}

The majority of Sembungan villagers are Muslims, there are only 2 families who are Christians, incidentally migrants. As a homogeneous society in rural religions and 
differences in religious orientation bring forth a religious attitude [12]. First, The devout Moslem, which is to exercise faith seriously. Secondly, Islamic KTP (Kartu Tanda Penduduk), which is only in the form of acknowledgment stated in the KTP, rarely carries out obligations such as the five daily prayers and Ramadan fasting for Muslims. To describe the adherence of a Muslim, at least they have prayed Friday or holidays to the mosque, fasting in the month of Ramadan, and giving alms, infaq or zakat. While Islam ID cards are recorded in Islamic KTPs, they are rarely seen in religious activities.

Table 1. Worship facilities.

\begin{tabular}{|c|l|c|c|l|}
\hline Number & \multicolumn{1}{|c|}{ Hamlet } & Mosque & Mushola & $\begin{array}{c}\text { The tendency } \\
\text { of CSOs }\end{array}$ \\
\hline 1 & Sembungan & 1 & 1 & Muhammadiyah \\
\hline 2 & Rejomulyo & 1 & - & Salafi \\
\hline 3 & Kepoh & 1 & - & Mix \\
\hline 4 & Mlokolegi Kidul & 1 & - & NU \\
\hline 5 & Mlokolegi Lor & 1 & - & Mix \\
\hline 6 & Bekangan & 1 & 2 & Muhammadiyah \\
\hline 7 & Tarub & 2 & 1 & Muhammadiyah \\
\hline 8 & Karangjoho Etan & 1 & 1 & NU \\
\hline 9 & Karangjoho Kulon & 1 & - & NU \\
\hline 10 & Cabean & 1 & - & MTA \\
\hline 11 & Asemgrowong & 1 & 1 & Muhammadiyah \\
\hline
\end{tabular}

The procurement of worship facilities, both mosques and mosques, is built on community self-help through the movements of Infaq, Sedeqah, and zakat as social awareness as religious communities. All of the 11 hamlets have mosques as a place of worship and some hamlets also have a mosque to overcome the inadequate capacity of the mosque or the distance of residents to places of worship, in addition to the tendency of differences in religious understanding (sect, faction). The practice and religious understanding divided into 5 groups, namely. Muhammadiyah (Modernist Islam), NU (Traditionalist Islam), Salafi (conservative), MTA (puritan) and Mixed (Moderate Islam).

Table 2. Religion institution.

\begin{tabular}{|c|l|l|l|}
\hline Number & \multicolumn{1}{|c|}{ Name } & \multicolumn{1}{|c|}{$\begin{array}{c}\text { Religion } \\
\text { Institution } \\
\text { Majelis Taklim }\end{array}$} & $\begin{array}{l}\text { Institutional } \\
\text { Development Place } \\
\text { Madrasah Diniyah \& } \\
\text { Homes }\end{array}$ \\
\hline 1 & Sembungan & Majelis Taklim & Homes \\
\hline 3 & Rejomulyo & Yasinan & Homes \\
\hline 4 & Mlokolegi Kidul & Yasinan & Homes \\
\hline 5 & Mlokolegi Lor & Majelis Taklim & Homes \\
\hline 6 & Bekangan & $\begin{array}{l}\text { Majelis Taklim } \\
+ \text { Yasinan }\end{array}$ & $\begin{array}{l}\text { Madrasah Ibtidaiyah } \\
\text { \& Homes }\end{array}$ \\
\hline 7 & Tarub & Yasinan & Homes \\
\hline 8 & Karangjoho Etan & Yasinan & Homes \\
\hline 9 & Karangjoho Kulon & Yasinan & Homes \\
\hline 10 & Cabean & $\begin{array}{l}\text { Majelis Taklim } \\
\text { Yasinan }\end{array}$ & Homes \\
\hline 11 & Asemgrowong & $\begin{array}{l}\text { Majelis Taklim } \\
+ \text { Yasinan }\end{array}$ & $\begin{array}{l}\text { Madrasah Ibtidaiyah } \\
\text { \& Homes }\end{array}$ \\
\hline
\end{tabular}

Although the religious structure of rural communities has a tendency to practice and understand a variety through religious education institutions, majelis taklim and recitation 
groups, or groups of yasinan, there are always efforts to promote social solidarity (prioritizing the social interests) [13]. As illustrated in table 2 related to the existing religious institutions, the pattern built by religious leaders; first, developing a sense of togetherness in religion to realize the unity of the people, that all religions are formally different but the core and essence are the same. Second, developing the understanding that true religion is only one, and is passed on to humans in different historical and sociological conditions, then religion in the historical context is always present in the same one. This means that in this context every religion has something in common with others, but at the same time also has a specificity, so that different understanding of something natural. Third, develop awareness of one's religiosity or group through worship activities together.

\subsection{The function of religion for rural communities}

Basically rural communities are formed from solidarity and consensus. Solidarity or social adhesive is the basis for the formation of organizations in society, while consensus is a mutual agreement on norms that give direction and meaning to group life [14]. The norm that gives direction and meaning to people's lives is religion. Religion problems cannot be separated from people's lives, because religion itself is needed in the life of society. In practice religious functions in society include:

Table 3. Meaning of religious functions.

\begin{tabular}{|c|c|c|c|}
\hline Number & $\begin{array}{l}\text { Meaning of } \\
\text { religious }\end{array}$ & Activity Form & Action \\
\hline 1 & Educative & $\begin{array}{l}\text { 1. } \begin{array}{l}\text { Recitation for knowing orders and } \\
\text { prohibitions }\end{array} \\
\text { 2. Order as obligation, prohibition as } \\
\text { Sin }\end{array}$ & $\begin{array}{l}\text { 1. Recitation, establishment } \\
\text { of the taklim assembly } \\
\text { 2. Congregational Prayer }\end{array}$ \\
\hline 2 & Savior & $\begin{array}{l}\text { 1. Believing the existence of the } \\
\text { world and the hereafter and } \\
\text { avoiding torture } \\
\text { 2. Unite yourself with God } \\
\text { 3. Recognition outside himself that } \\
\text { there is a more powerful force }\end{array}$ & $\begin{array}{l}\text { 1. Increase the virtue for } \\
\text { others } \\
\text { 2. Share some of the assets } \\
\text { owned to others }\end{array}$ \\
\hline 3 & Atonement & $\begin{array}{l}\text { 1. Liberation of guilt through prayer } \\
\text { 2. Manage assets as they should and } \\
\text { limit the love of property }\end{array}$ & $\begin{array}{l}\text { 1. Always be positively } \\
\text { prejudiced } \\
\text { 2. Get used to mutual respect }\end{array}$ \\
\hline 4 & $\begin{array}{l}\text { Social } \\
\text { control }\end{array}$ & $\begin{array}{l}\text { 1. An attitude of self-introspection } \\
\text { over the deficiencies } \\
\text { 2. Feeling every behavior supervised } \\
\text { by God }\end{array}$ & $\begin{array}{l}\text { 1. Diligent friendship } \\
\text { 2. Always attend religious } \\
\text { celebrations }\end{array}$ \\
\hline 5 & $\begin{array}{l}\text { Transformat } \\
\text { ive }\end{array}$ & $\begin{array}{l}\text { 1. Having religious beliefs to help } \\
\text { people } \\
\text { 2. Work done on the orders of } \\
\text { Religion }\end{array}$ & $\begin{array}{l}\text { Giving, Assisting, Helping } \\
\text { parts of life's tasks }\end{array}$ \\
\hline 7 & Creative & $\begin{array}{l}\text { Religion as a medium resolves } \\
\text { problems faced by individuals }\end{array}$ & $\begin{array}{l}\text { Hard work, smart work is part } \\
\text { of the purpose of God's } \\
\text { command }\end{array}$ \\
\hline 8 & Sublimative & $\begin{array}{l}\text { 1. Realizing the attributes of God in } \\
\text { Humans } \\
\text { 2. Understanding God's } \\
\text { Commandments }\end{array}$ & $\begin{array}{l}\text { Humanizing humans through } \\
\text { participating in solving } \\
\text { human problems by giving } \\
\text { help }\end{array}$ \\
\hline
\end{tabular}

From table 3 , it is explained that socially the motivation to perform rituals is different, mostly to get more merit from God than others, even though some others are driven by 
spiritualism. Religiosity values in religious ritual activities are at the core of religious awareness about the relationship between humans and their God that they get to know again about God, as well as a means of communication. Prayer for Muslims, is a sacred worship that protects people from situations of chaos in life. Prayer is the culmination of the teaching of the highest truth.

Therefore, sociologically, ritual teaching is a symbol for followers who are religious human beings, and symbolically gives meaning to balance in human life. Rituals for rural communities are doctrines that provide moral guidelines for carrying out life in a social world in the form of obedience and togetherness. Prayer in mosques is a reflection of the religious behavior of rural communities. The mosque is a representation of personal piety and social piety. Individual piety as proof of obedience in carrying out the teachings, and social piety is reflected in prayer together (congregation), which describes not being selfish and not forgetting their social obligations. This is where the need is to build individual and social piety together, to fulfill the self-interests and interests of others.

The awareness of the practice of charity (zakat, infaq and alms) carried out by rural communities is based on the understanding and belief that the possessions that are then given to people will increase if used for religious purposes. The culture of giving is still understood as a social domain. Increasing family income has an effect on the practice of giving donation to the peasant community in building the religiosity of the village elite class. While the village elite has a commitment to the poor and weak symbolically represented donations for the reason that the salary that has been received exceeds the limit required to pay zakat, charity orientation to keep the holy messages.

\subsection{Social adhesives}

Social adhesive tools in the context of diversity, including; First, religious knowledge. For rural communities, knowledge is gained through social interaction through studies, recitation, sermons in mosques, churches or moments of religious ceremonies, which present religious leaders with the community. According to Berger [15] dialectic religious knowledge is a process of three momentum, namely externalization, objectivation, and internalization. Externalization of knowledge as a means of expressing itself as part of human beings. Objectivation is knowledge that is separate from humans and dealing with humans. Internalization is the knowledge of society as its social institutions influence and shape human behavior. The social structure that is formed is supported by the existence of facilities in the environment, it can be in the form of non-formal education facilities which become the reinforcement of its social capacity [16]-[18].

Second, religious rural communities are able to create harmony. Religion plays a role as law enforcement and keeps the community subject to the law. If in a religious society does not have a role, it can be ascertained that the social life of the community experiences moral decadence and chaos that affects the nation and the state. Religion shapes social life through the values that is thought. Spiritual value can maintain environmental stability, and can be mutually tolerant, understand each other between communities to form civil society [19].

Third, religion in politics is as a revelation, which is interpreted: (a) a belief system (belief system) and a system of normative rules (normative system) from God, to regulate human life by God, humans with humans and humans with other realms, (b ) belief systems aim at directing the happiness of the world and the hereafter. Religious rites are performed to show the correlation of personal religiosity in daily life. Religiosity always shows the experience of individual middle class people with various modernities tend to foster cognitive society not in accordance with religious teachings. Rationalization, materialism 
and positivesme are factors of modernity that influence the religious awareness of the community.

\section{Conclusion}

Understanding the religious phenomena as formulated by Emile Durkheim is functional. Religion is not just a doctrine of supernatural problems, manuscripts, but a social phenomenon that reflects cohesiveness (glue) and social solidarity. The concept of morality is built as a collective consciousness that binds groups of people collectively. Ethical or religious life depends on cohesion and solidarity between individuals. Rural communities have a tendency to make new interpretations of the system of religious values and norms that are believed and lived by the community and then express values of appreciation in the form of efforts to maintain togetherness through functional religious messages. When the new meaning of individuals in the community is often trapped in conflict of interest which is influenced by the material, then it takes something of the power of transcendent values. The discovery of this new transcendent meaning is then called the awareness of collectivity, solidarity and social glue in religion.

The social relation between religion and society has an important meaning when defining religion so that it forms a social system and is able to interact with various economic, social, cultural aspects, this is related to the interpretation of religious teachings by the community, religious dialogue regarding religion and modernity. Religion is a force that unites society. If there is a difference between individuals or groups, the articulation of interests creates a shared ideology.

\section{References}

1. T. Roberts, Lifecycle Assessment for a Devoted Religious Adherent (Arizona State University School, 2012)

2. A.R. Radcliffe-Brown, Structure and Function in Primitive Society: Essays and Addresses (ChiZine Publications, Ontario, 2017)

3. E. Schneier, J. Church State 60, 3, 540-541 (2018)

4. Koentjaraningrat, Villages in Indonesia. (Equinox Publishing, Singapore, 2007)

5. A.N. Whitehead, Religion in the Making. 1926 (Fordham UP, New York, 1996)

6. G. Saucier and K. Skrzypińska, J. Pers. 74, 5, 1257-1292 (2006).

7. M.Q. Patton, Qualitative Research \& Evaluation Methods: Integrating Theory and Practice (SAGE Publications, California, 2015)

8. J. A. Smit, Altern. J. 11, 10-35 (2013).

9. Koentjaraningrat, Manusia dan kebudayaan di Indonesia. Djambatan, Jakarta, 2007)

10. J.L. Martin, Social Structures (Princeton University Press, Princeton, 2011)

11. W.A. Jackson, Rev. Soc. Econ. 63, 1, 101-124 (2005)

12. C. Kersten, Islam in Indonesia: the contest for society, ideas and values (University Press, Oxford, 2015)

13. C.Y. Hoon, Asian Stud. Rev. 41, 3, 476-493, (2017)

14. K.I. Maton and E. A. Wells, J. Soc. Issues 51, 2, 177-193, (1995)

15. P.L. Berger, Langit Suci: Agama sebagai Realitas Sosial [The Desecularization of the World: Resurgent Religion and World Politics] (LP3ES, Jakarta, 1991)

16. P. Suharso and S. Sarbini, E3S Web Conf. SCiFiMaS 2018, 47, 7004, 1-6 (2018)

17. P. Suharso, B. Sudardi, S.T. Widodo, and S.K. Habsari, IOP Conf. Ser. Earth Environ. Sci. 116, 12002 (2018)

18. P. Suharso, B. Sudardi, S.T. Widodo, and S.K. Habsari, E3S Web Conf. SCiFiMaS 
2018 47, 7005, 1-6 (2018)

19. R.W. Hefner, Rev. Faith Int. Aff. 11, 2, 18-27 (2013) 